Original Artikel

\title{
Pengaruh Pembelajaran Guided Inquiry Small Research Terhadap Keterampilan Proses Sains Siswa Pada Materi Bakteri di SMA NU Juntinyuat
}

\author{
Indra Drajat Sopwan ${ }^{1}$ dan Yuli Arnita Sari ${ }^{2}$ \\ ${ }^{1,2}$ Program Studi Pendidikan Biologi, STKIP Pangeran Dharma Kusuma Sageran Juntinyuat, Indramayu, \\ Indonesia, 45282 \\ Email: indrasopwan@gmail.com, yuliarnita89@gmail.com
}

\begin{abstract}
This study aimed to analyze the The Effect of Learning Guided Inquiry Small Research Against Student Science Process Skills on Bacteria Material in Senior Hight School NU Juntinyuat. The method used Posttest-Only Control Design. The population in this study is the class X.1 and X.2 Senior High School NU Juntinyuat in 2019/2020 school year and totaling 52 students. Sampling was done by using cluster random sampling, were divided into 2 groups: Guided Inquiry model class with 26 students and other class are not using Guided Inquiry as many as 26 students. Instruments in this research is the description of science process skills, observation sheets and questionnaires for students. Hypothesis test using parametric statistical tests in this case to test the hypothesis of The Effect of Learning Guided Inquiry Small Research models to enhance the critical thinking skills using Manova test was obtained $p<0.05$ is $0.042<0.05$, which means there is an increased The Effect of Learning "Guided Inquiry Small Research"of critical thinking skills of students.
\end{abstract}

Kata Kunci: guided inquiry, science process skills

\section{PENDAHULUAN}

Perkembangan ilmu pengetahuan dan teknologi yang pesat di era global sekarang ini menuntut individu untuk berkembang menjadi manusia berkualitas yang memiliki pemikiran dalam menjawab segala tantangan dan permasalahan yang ada. Pendidikan sebagai salah satu sistem yang menjawab tuntutan ini juga mengalami perubahan seiring dengan perkembangan zaman. Model pembelajaran inkuiri terbimbing (Guided Inquiry) model pembelajaran yang tepat digunakan untuk melatih berdasarkan fakta - fakta, proses investigasi berupa penemuan pada saat pembelajaran. Pembelajaran agar lebih bermakna diharapkan mampu mengaitkan halhal yang telah dipelajari di kelas dengan kehidupan nyata, salah satunya dengan mengembangkan konsep atau materi dengan kontruktivisme, yaitu filosofi belajar yang menekankan bahwa belajar tidak hanya sekedar menghafal tetapi mengkontruksi atau membangun pengetahuan dan keterampilan baru, lewat fakta-fakta yang mereka alami dalam kehidupannya. Salah satu pembelajaran kontruktivisme adalah pembelajaran mini riset. 
Salah satu metode yang tepat dalam mata pelajaran Biologi adalah metode inkuiri terbimbing (guided inquiry). Dalam metode inkuiri terbimbing siswa diberi kesempatan untuk memiliki pengalaman belajar yang nyata dan aktif serta dilatih bagaimana memecahkan masalah sekaligus membuat suatu keputusan. Berdasarkan penelitian sebelumnya, penerapan metode inkuiri terbimbing lebih efektif daripada metode konvensional dalam meningkatkan hasil belajar siswa pada materi hidrolisis garam serta memberikan pengaruh positif terhadap kemampuan inkuiri siswa (Octadhia, 2011). Sehingga penggunakan pemebelajaran inkuri dapat digunakan untuk meningkatkan hasil belajar siswa dan keterampilan eksperimen siswa dengan keterampilan berpikir sains. Dimana keterampilan pada siswa cenderung tidak aktif pada saat pembelajaran, selama ini siswa hanya sebatas kepada teori saja sehingga pengembangan pembelajaran hanya terpaku kepada guru teacher center, pada kurikulum

\section{METODOLOGI PENELITIAN}

Metode dalam penelitian ini adalah Eksperimental. Metode ini mempunyai kelompok kontrol, tetapi tidak dapat berfungsi sepenuhnya untuk mengontrol variabel-variabel luar yang mempengaruhi pelaksanaan eksperimen (Sugiyono, 2013). Penelitian ini menggunakan desain Posttest-Only Control Design. Dengan desain ini sample dibagi menjadi dua kelompok yang masing-masing dipilih secara random (R). Kelompok pertama diberi perlakuan (X) dan kelompok yang lain tidak (Sugiyono, 2013).

Pada posttest-only control design ini tidak adanya pretest karena telah dilakukannya randomisasi dengan menggunakan teknik sampling cluster random sampling untuk menentukan kelompok eksperimen berjumlah 26 siswa dan kelompok kontrol berjumlah 26 siswa. Penerapan desain ini dapat mengukur pengaruh
2013 pembelajaran melibatkan tiga komponen yang termasuk dalam penilaian diantaranya penilaian pengetahuan (kognitif), penilaian sikap (afektif) dan penilaian psykomotorik (keterampilan).

Keterampilan poses sains atau scientific process skills diartikan oleh Depdikbud (dalam Dimyati, 2009) sebagai wawasan pengembangan keterampilan-keterampilan intelektual, sosial, dan fisik yang bersumber dari kemampuan mendasar yang telah ada dalam diri siswa. Pembelajaran Biologi saat ini umumnya hanya menekankan pada aspek produk sains dan kurang mengembangkan aspek proses dan sikap sains. Senada dengan hal tersebut Rustaman dan Nuryani (2005) mengatakan bahwa pengetahuan yang didapat pada saat ini sudah di informasikan dengan berbagai cara, sehingga orang-orang lebih terpaku pada produk sains. Keterampilan proses sains perlu dikembangkan karena di dalamnya terdapat keterampilan kognitif, manual, dan sosial (Prasetyo, 2013).

treatment pada kelompok eksperimen dengan cara membandingkan kelompok tersebut dengan kelompok kontrol. Untuk kelompok eksperimen menggunakan inkuiri terbimbing berbasis mini riset pada materi bakteri, sedangkan untuk kelompok kontrol menggunakan inkuiri terbukapada materi bakteri. Dua kelompok tersebut melakukan post-test untuk melihat seberapa besar kaitannya antara aplikasi pembelajaran inkuiri terbimbing berbasis mini riset terhadap keterampilan proses sains. Observasi dilakukan sebanyak dua kali yaitu sesudah perlakuan (treatment). Observasi yang dilakukan sesudah perlakuan $\left(\mathrm{O}_{1}\right.$ dan $\left.\mathrm{O}_{2}\right)$ disebut tes akhir (Posttest). Dalam penelitian ini terdapat variabel terikat yaitu keterampilan proses sains, dan variabel bebas yaitu pembelajaran inkuiri terbimbing berbasis mini riset. Teknik analisis data ini menggunakan ujigain dan uji $T$. 


\section{HASIL DAN PEMBAHASAN}

Pada penelitian ini, terdapat dua kelompok sampel yang di uji, yaitu kelas eksperimen dan kelas kontrol. Antara kelas eksperimen dan kelas kontrol diberikan perlakuan yang berbeda, kelas eksperimen pada saat proses pembelajaran menggunakan model pembelajaran Inkuiri Terbimbing (Guided Inquiry), sedangkan kelas kontrol menggunakan metode diskusi. Kelas eksperimen dan kelas kontrol diberikan tes uraian yang sama pada saat posttest, sedangkan untuk instrument yang lain seperti angket dan lembar observasi pada tabel 1 hanya dilakukan pada kelas eksperimen.

Tabel 1. Data Hasil Lembar Observasi

\begin{tabular}{|c|c|c|c|c|}
\hline No & Tahapan Pembelajaran & Jumlah Aspek & $\begin{array}{c}\text { Jumlah } \\
\text { Terlaksana }\end{array}$ & $\begin{array}{c}\text { Jumlah Tidak } \\
\text { Terlaksana }\end{array}$ \\
\hline 1. & Kegiatan Pendahuluan & 3 & 2 & 1 \\
\hline \multirow[t]{7}{*}{2.} & \multicolumn{4}{|c|}{$\begin{array}{l}\text { Kegiatan Inti } \\
\text { Tahapan Model Pembelajaran Inkuiry Terbimbing (Guided Inquiry) }\end{array}$} \\
\hline & Fase 1. Orientasi & 2 & 2 & - \\
\hline & Fase 2. Merumuskan masalah & 4 & 4 & - \\
\hline & Fase 3. Merumuskan hipotesis & 1 & 1 & - \\
\hline & Fase 4. Mengumpulkan data & 2 & 2 & - \\
\hline & Fase 5. Menguji hipotesis & 1 & 1 & - \\
\hline & Fase 6. Merumuskan kesimpulan & 1 & 1 & \\
\hline 3. & Kegiatan Penutup & 7 & 7 & - \\
\hline \multicolumn{2}{|c|}{ Jumlah } & 21 & 21 & - \\
\hline & Persentase & \multicolumn{2}{|c|}{$100 \%$} & $0 \%$ \\
\hline
\end{tabular}

Berdasarkan hasil lembar observasi bahwa sikap dan langkah-langkah yang dilakukan oleh guru dan siswa mengenai proses pembelajaran model inkuiry terbimbing telah terlaksana dengan baik, tetapi ada beberapa langkah yang tidak terlaksana pada proses pembelajaran. Tahapan yang tidak terlaksana 0\% dan tahapan yang terlaksana dengan persentase sebesar $100 \%$.

Keterampilan proses sains diukur menggunakan tes uraian yang dilaksanakan di dua kelas yang diuji, yaitu kelas eksperimen dan kelas kontrol. Pada penelitian ini dilaksanakan 1 kali posttest untuk melihat Keterampilan proses sains siswa setelah diberi perlakuan, jumlah soal yang digunakan pada posttest yaitu 5 soal dengan masing - masing indikator Keterampilan proses sains dengan konsep materi bakteri. Setelah dilakukan penskoran terhadap hasil posttestdengan menggunakan rubrik penskoran, didapatkan hasil rata-rata perolehan nilai posttest keterampilan proses sains seperti pada tabel 2 berikut ini : 
Tabel 2. Skor Rata-Rata Kemampuan Proses Sains

\begin{tabular}{|c|c|c|}
\hline Kelas & Rata-Rata Skor Posttest & Keterangan \\
\hline Eksperimen & 2,74 & Sedang \\
\hline Kontrol & 2,56 & Sedang \\
\hline
\end{tabular}

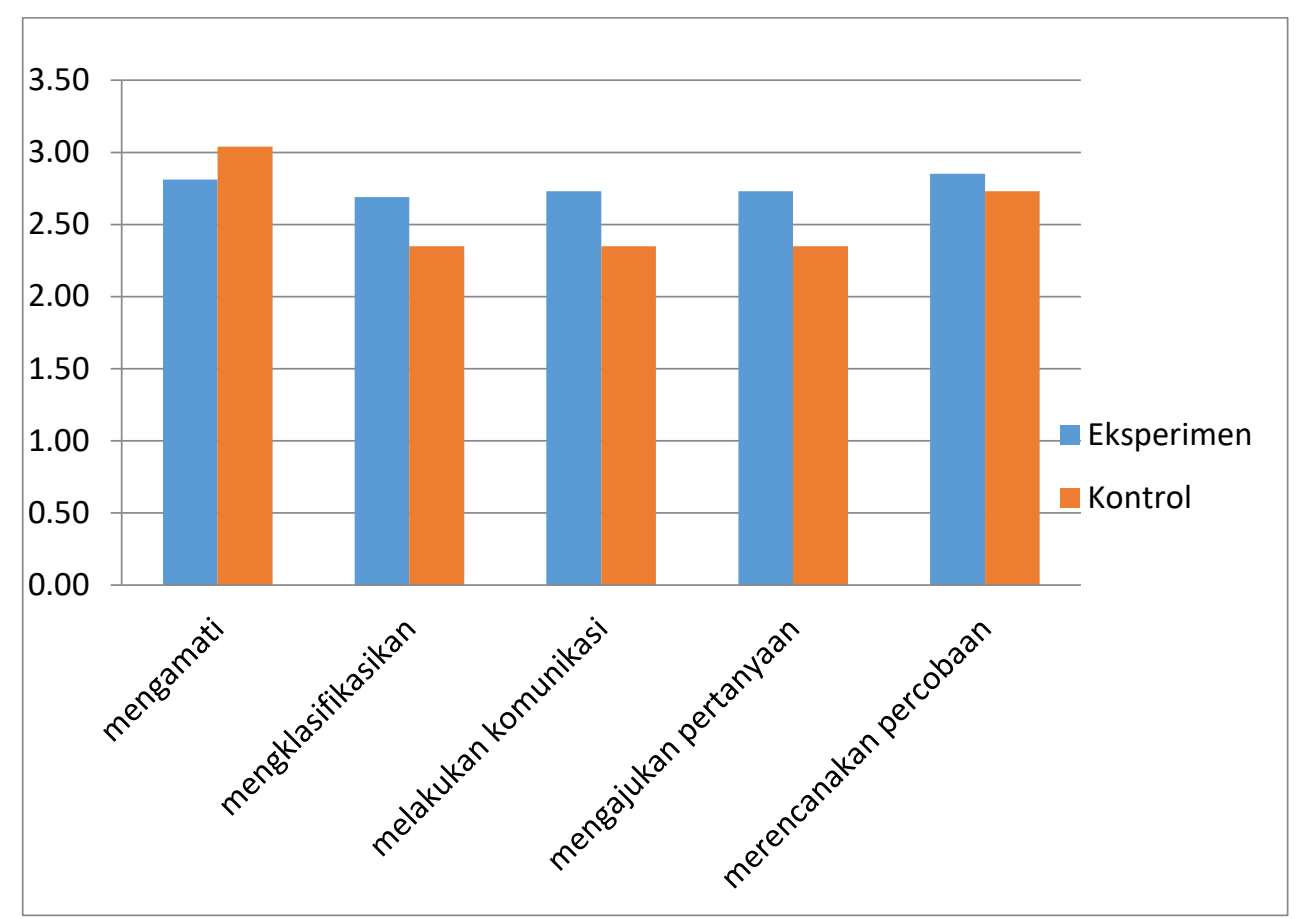

Gambar 1. Hasil Posttest Keterampilan Proses Sains Siswa pada Setiap Indikator

Adapun persentase siswa yang mampu menyelesaikan soal posttest dari setiap indikator keterampilan proses sains tersebut dilihat pada gambar 1. Berdasarkan gambar 1terdapat perbedaan rata-rata hasil posttestuntuk setiap indikator. Pada kelas yang menerapkanmodel inkuiri terbimbingskor tertinggi keterampilan proses sains yaitu indikator mengamati sebesar 2,81, indikator mengklasifikasikan sebesar 2,69, indikator melakukan komunikasi sebesar 2,73, indikator mengajukan pertanyaan sebesar 2,73 dan indikator merencanakan percobaan sebesar 2,85. Adapun pada kelas yang menerapkan metode diskusi dengan skor keterampilan proses sains yaitu indikator mengamati sebesar 2,96, indikator mengklasifikasikan sebesar 2,12, indikator melakukan komunikasi sebesar 2,31, indikator mengajukan pertanyaan sebesar 2,35 dan indikator merencanakan percobaan sebesar 2,69 .

\section{Uji Normalitas Keterampilan Proses Sains}

Data diperoleh dari hasil postest pada kelas eksperimen dan kontrol. Uji normalitas menggunakan uji Kolmogrov-Smirnovdengan SPSS.Adapun hasil uji normalitas tes uraian seperti yang terdapat pada tabel 3 berikut. 
Tabel 3. Uji NormalitasKeterampilan Proses Sains

\begin{tabular}{|c|c|c|c|c|}
\hline Kelas & Nilai & $\mathbf{Z}$ & $\boldsymbol{\alpha}$ & Kesimpulan \\
\hline Eksperimen & Postest & 0,110 & 0,05 & Normal \\
\hline Kontrol & Postest & 0,103 & 0,05 & Normal \\
\hline
\end{tabular}

Keterangan :

$\mathrm{Z}:$ Kolmogorov-Smirnov

$\alpha$ : taraf signifikasn $0,05(\mathrm{p}>0,05)$

Jika $Z>0,05$ distribusi normal

Karena data postest eksperimen tersebut memiliki nilai $Z>0,05$ yaitu $0,110>0,05$, maka dapat disimpulkan bahwa data tersebut berdistribusi normal. Begitupula data postest kelas kontrol memiliki nilai $\mathrm{Z}$ lebih dari 0,05 yaitu $0,103>0,05$, maka data tersebut berdistribusi normal sehingga dilanjutkan pada uji homogenitas.

\section{Uji Homogenitas Keterampilan Proses Sains}

Pada uji homogenitas data yang diperoleh, yaitu data hasil postest dari kelas eksperimen dan kontrol. Uji homogenitas menggunakan uji Levene dengan SPSS. Adapun hasil uji homogenitas tes uraian terdapat pada tabel 4 berikut.

Tabel 4. Uji Homogenitas Keterampilan Proses Sains

\begin{tabular}{|c|c|c|c|}
\hline Kelas & Levene Statistic & Sig. & Kesimpulan \\
\hline Eksperimen dan Kontrol & 1.356 & 0,434 & Homogen \\
\hline
\end{tabular}

Berdasarkan Tabel 4 di atas bahwa data Kemampuan bernalar homogen karena $p>0,05$ yaitu $0.434>0,05$, sehingga dapat dilanjutkan uji hipotesis menggunakan $U j i$ t. Dalam penelitian ini menggunakan uji $t$ karena terdapat satu variabel independen dan satu variabel depende. Adapun hasil hipotesis uji $t$ dapat dilihat pada Tabel 2 sebagai berikut

Tabel 5. Hasil Uji $t$

\begin{tabular}{|c|c|c|}
\hline Variabel & Sig. & Kesimpulan \\
\hline Keterampilan Proses Sains & 0,042 & $\mathrm{p}<0,05$, tolak Ho \\
\hline
\end{tabular}

Dari Tabel 5 dapat disimpulkan bahwa pengaruh pembelajaran Inkuiri Terbimbing berbasis mini riset terhadap keterampilan proses sains, hasil uji hipotesis menunjukkan bahwa tolak Ho artinya pembelajaran Inkuiri
Terbimbing berbasis mini riset berpengaruh terhadap ketereampilan proses sains siswa.

Adapun hasil analisis angket siswa diperoleh hasil respon siswa terhadap pembelajaran inkuiri terbimbing berbasis mini riset terhadap keterampilan proses sains bahwa 
dari setiap butir pernyataan diperoleh persentase lebih dari $83 \%$ dengan interpretasi kuat yang menunjukkan bahwa untuk pernyataan positif respon siswa setuju dengan pernyataan tersebut dan untuk pernyataan negatif siswa tidak setuju dengan pernyataan yang terdapat pada angket tersebut. Dari data yang dijelaskan dapat membuktikan respon siswa terhadap pembelajaran dengan menggunakan inkuiri terbimbing berbasis mini riset yaitu positif dan menarik perhatian dan mtivasi siswa untuk belajar.

Tabel 6. Persentase Pada Setiap Item Angket

\begin{tabular}{|c|l|c|c|c|}
\hline No & \multicolumn{1}{|c|}{ Indikator } & $\begin{array}{c}\text { Klasifikasi } \\
\text { pernyataan }\end{array}$ & Persentase & Keterangan \\
\hline 1. & $\begin{array}{l}\text { Masalah yang dimunculkan } \\
\text { familiar }\end{array}$ & Positif, Positif & $79 \%$ & Cenderung Setuju \\
\hline 2. & $\begin{array}{l}\text { Banyak memiliki solusi } \\
\text { alternatife }\end{array}$ & Positif & $83 \%$ & Cenderung Setuju \\
\hline 3. & Keaktifan peserta didik & Negatif, Positif & $77 \%$ & Cenderung Setuju \\
\hline 4. & $\begin{array}{l}\text { Mengintegrasikan dengan } \\
\text { pengetahuan } \\
\text { masalah di kehidupan nyata }\end{array}$ & Positif, Positif & $80 \%$ & Cenderung Setuju \\
\hline 5. & Pemahaman materi & Positif & $80 \%$ & Cenderung Setuju \\
\hline 6. & $\begin{array}{l}\text { Kemampuan memecahkan } \\
\text { masalah }\end{array}$ & Positif, Negatif & $83 \%$ & Cenderung Setuju \\
\hline
\end{tabular}

Model pembelajaran ini dapat diterima oleh siswa karena sebelumnya belum pernah menggunakan model seperti ini pada saat pembelajaran dan mampu membuat siswa tertarik dan termotivasi walaupun tidak mencapai $100 \%$ tetapi proses pembelajaran cukup dapat diterima oleh siswa. Jadi dapat disimpulkan bahwa tiap tahap selama proses pembelajaran dapat terlaksana dengan baik.

Keterlaksanan proses pembelajaran inkuiri berbasis mini riset mencapai $100 \%$. Dalam masing - masing tahapan (sintaks) pemmbelajaran ini menggunakan metode eksperimen, presentasi, diskusi kelompok dan tanya jawab serta dengan LKS yang sesuai dengan pembelajaran. Pembagian pada kelompok pembelajaran sangat bermanfaat bagi proses pembelajaran, dimana siswa dapat mengembangkan pola pikir dari setiap antar individu maupun secara bekerja kelompok untuk memecahkan suatu permasalahan dan saling mengahargai dalam tingkat keberhasilan pembelajaran dikelas yang dilakukan oleh guru dan siswa. Hal ini senada dengan pernyataan Arnita Sari (2017) menyatakan Keberhasilan atau kegagalan dalam pembelajaran ini dapat dipengaruhi oleh kompetensi dan antusiasme siswa dan guru. Pada efektivitas dari pendekatan pembelajaran dengan cara eksperimen dibentuk kelompok - kelompok kecil dapat bergantung pada setiap pengembangan kemampuan diri siswa yang dianggap berbeda - beda. Shamsudin et al, (2011) menyatakan bahwa eksperimen merupakan inti dari melakukan penyelidikan dalam kelas sains. Melalui ekseperimen juga membuat siswa mampu melihat atau menghubungkan konsep teroiti dan praktek dengan lebih baik pada materi pelajaran.

Tujuan dari penelitian ini adalah untuk mengetahui pengaruh pembelajaran inkuri terbimbing berbasis mini riset terhadap keterampilan proses sains pada materi bakteri di kelas X Mia 1 dan kelas X Mia 2.Kelas X Mia 1 menjadi kelas eksperimen dengan pembelajaran menggunakan model inkuri terbimbing sedangkan kelas X Mia 2 menjadi kelas kontrol 
dengan pembelajaran diskusi. Berdasarkan hasil lembar observasi menunjukkan langkah-langkah dalam model inkuri dapat dilaksanakan dengan baik sesuai dengan yang telah direncanakan dengan persentase $100 \%$.

Berdasarkan rata-rata nilai postest siswa pada keterampilan proses sains kelas eksperimen 2,74 sedangkan yang kelas kontrol 2,56 disini mempunyai perbedaan dari kedua kelompok tersebut. Setelah mengetahui rata-rata dari nilai kedua kelas maka dilakukan uji normalitas didapatkan data Karena data postesteksperimentersebut memiliki nilai $\mathrm{Z}>$ 0,05 yaitu $0,110>0,05$, maka dapat disimpulkan bahwa data tersebut berdistribusi normal. Begitupula data postest kelas kontrol memiliki nilai $\mathrm{Z}$ lebih dari 0,05 yaitu $0,103>0,05$, maka data tersebut berdistribusi normal sehingga dilanjutkan pada uji homogenitas. Maka dilanjutkan menguji data dengan homogenitas didapatkan data keterampilan proses sains homogen karena $\mathrm{p}>0,05$ yaitu $0.434>0,05$, sehingga dapat dilanjutkan uji hipotesis menggunakan $U j i$ t. Data hasil uji hipotesis didapatkan $0,042<0,05$ bahwa pengaruh pembelajaran Inkuiri Terbimbing berbasis mini riset terhadap keterampilan proses sains, hasil uji hipotesis menunjukkan bahwa tolak Ho artinya pembelajaran Inkuiri Terbimbing berbasis mini riset berpengaruh terhadap keterampilan proses sains siswa. Adapun tahapan inkuiri terbimbing memiliki langkah-langkah di dalam proses pembelajarannya, diantaranya:

1. Orientasi

Guru merangsang dan mengajak siswa untuk berpikir memecahkan masalah. Langkah orientasi merupakan langkah yang sangat penting karena merupakan langkah awal untuk menarik perhatian dan pemikiran siswa.

2. Merumuskan Masalah

Guru memberikan masalah yang akan dibahas atau untuk diselidiki dan dipecahkan melalui kegiatan eksperimen.
3. Merumuskan Hipotesis

Guru mengajak siswa membuat dugaan awal mengenai hasil praktikum berdasarkan rumusan masalah yang dibuat.

4. Mengumpulkan Data Mengumpulkan data adalah aktivitas menjaring informasi yang dibutuhkan untuk menguji hipotesis yang telah diajukan.

5. Menguji Hipotesis

Menguji hipotesis adalah proses menetukan jawaban yang dianggap diterima sesuai dengan data atau informasi yang diperoleh berdasarkan pengumpulan data.

6. Merumuskan Kesimpulan Merumuskan Kesimpulan adalah proses mendeskripsikan temuan yang diperoleh berdasarkan hasil pengujian hipotesis.

Pembelajaran inkuiri memfasilitasi dalam pengamatan atau ekseperimen baik itu sekala besar atau kecil seperti mini riset. Mini riset adalah model pembelajaran yang menggunakan masalah sebagai langkah awal dalam mengumpulkan informasi dan mengolah informasi. Melalui model pembelajaran tersebut siswa di fasilitasi untuk merancang sendiri proyek yang akan dilakukan, sehingga siswa dapat melakukan eksplorasi, penilaian, interpretasi, sintesis dan informasi (Kemendikbud, 2013). Inkuiri terbimbing cocok diterapkan di SMA karena sesuai dengan karakteristik siswa SMA yang cenderung kurang mandiri dan masih membutuhkan saran dan isyarat dari guru (Rokhmatika dkk, 2012).

Untuk siswa dikelompok eksperimen dengan pembelajaran inkuiri terbimbing berbasis mini riset dapat mengembangkan kemapuan berpikir, menalar dan memecahkan masalah interdisiplin dengan lembar kerja siswa yang diberikan untuk ditugaskan berkelompok dengan berisi bagian dari indikator keterampilan proses sains dengan kemampuan hasil yang rata dari 
setiap indikatornya. Bedahalnya dengan kelopok diskusi siswa kurang terlatih untuk mengembangkan kempuan berpikir dalam memecahkan masalah pada posttest kelas kontrol mempunyai tingkatan yang tinggi pada indikator mengamati. Adapun hasil respon siswa terhadap pembelajaran inkuri terbimbing berbasis mini riset diperoleh persentase lebih dari $83 \%$ meskipun tidak mencapai $100 \%$ tapi dari respon siswa terhadap keterampilan proses sainspada proses pembelajaran sangat terlaksana dengan baik.

\section{SIMPULAN}

Berdasarkan hasil analisis data dan pengujian hipotesis penelitian yang telah dilaksanakan maka peneliti menyimpulkan implementasi pembelajaran inkuriri terbimbing berbasis mini riset terhadap keterampilan proses sains siswa pada konsep bakteri, secara keseluruhan hasil penelitian yang dilakukan diantaranya:
1) Ada keterlaksanaan proses pembelajaran inkuiri terbimbing berbasis mini riset telah terlaksana dengan baik.

2) Adanya pengaruh pembelajaran inkuri terbimbing berbasis mini riset terhadap keterampilan proses sains

3) Adanya respon siswa terhadap pengaruh pembelajaran inkuiri terbimbing berbasis mini riset terhadap keterampilan proses sains siswa yang dilakukan di kelas eksperimen.

\section{DAFTAR PUSTAKA}

Amri, S. \& Ahmadi, L.K. 2010. Kontruksi Pengembangan Pembelajaran. Surabaya: Prestasi Pustaka Publisher.

Dimyati, dkk. 2009. Belajar Dan Pembelajaran. Jakarta: Rineka cipta

Haryono. 2006. Model Pembelajaran Berbasis Peningkatan Keterampilan Proses Sains. Jurnal Pendidikan Dasar 7(1). 1-13.

Kementerian Pendidikan dan Kebudayaan a. (2013). Salinan Permendikbud No. 65 Tahun 2013 tentang Standar Proses. Jakarta: Kemdikbud.

Octadhia, D. 2011. Efektifitas Penerapan Metode Inkuiri Terbimbing dalam Pembelajaran Kimia terhadap Motivasi dan Hasil Belajar Siswa Kelas XI IPA SMA Negeri 1 Gondanglegi pada Pokok Bahasan Hidrolisis Garam. Skripsi tidak diterbitkan. Malang: Jurusan Kimia FMIPA UM.

Prasetyo, 2013. Implementation of Guided Inquiry in Coordination System Material to Improve Science Process Skill at Class XI IPA 3 Students in SMA Batik 2 Surakarta in Academic Year 2013/2014. Jurnal Pendidikan Biologi Volume 7,Nomor 2 
Riduwan. 2010. Dasar - Dasar statistik. Bandung : Alfabeta

Rokhmatika, Siti., Harlita, dan Prayitno, B.A., (2012). Pengaruh Model Inkuiri Terbimbing dipadu Kooperatif Jigsaw Terhadap Keterampilan Proses Sains Ditinjau dari Kemampuan Akademik. Jurnal Pendidikan Biologi, Vol. 4, No. 2, 72-83.

Rustaman, Y. Nuryani. 2005. Strategi Belajar Mengajar Biologi. Malang: UN PRESS

Trianto. 2007. Model-model Pembelajaran Inovatif Berorientasi Konstruktivistik. Jakarta : Prestasi Pustaka

Shamsudin, et all. 2013. Strategis Of TeachingScience Usingan InquiryBased Science Education (IBSE) by Novice ChemistryTeachers" Procedia- Social and Behavioral Sciences. 90, 583 -592 .

Sugiyono. 2013. Metode Penelitian Pendidikan: Pendekatan Kuantitatif, Kualitatif dan R\&D. Bandung: Alfabet

Wulanningsih, Sri., Prayitno, B.A., dan Probosari, R.M. (2012). Pengaruh Model Pembelajaran Inkuiri Terbimbing Terhadap Keterampilan Proses Sains Ditinjau dari Kemampuan Akademik Siswa SMA Negeri 5 Surakarta. Jurnal Pendidikan Biologi, Volume 4, Nomer 2

Yuli, Arnita Sari. 2017. Penerapan Pembelajaran Berbasis Praktikum Untuk Meningkatkan Keterampilan Proses Sains Dan Sikap Imiah Siswa SMK Pada Materi Bakteri. Sinau Vol 3, No $02,1-18$ 